\title{
Comparison of Jumping Distance on Several Grasshopper Species (Orthoptera)
}

\author{
Ari Sugiarto \\ Email: sugiartoari13@gmail.com
}

\begin{abstract}
Grashhoppers have the jumping ability to move on one place to another place. Other than that, Grasshoppers use the jumping ability to escape from predators. The jumping distance of several grasshopper species is not expected to be the same, this led to the idea to conducting reseach to measure the jumping distance of several grasshopper species. This reasearch was conducted in a closed room with a size of $5 \mathrm{~m}$ x $5 \mathrm{~m}$. Grasshopper species measured by jumping distance are Atractomorpha crenulata, Gesonula mundata, Oxya hyla, and Xenocatantops humilis. The selection of these four grasshopper species is estimated to have different jumping distances. The result of the research showed that Oxya hyla have the farthest jumping distance compared to Atractomorpha crenulata, Gesonula mundata, and Xenocatantops humilis. Atractomorpha crenulata has the shortest jumping distance compared to Oxya hyla, Gesonula mundata, and Xenocatantops humilis. This difference in the jumping distance can estimated that Oxya hyla and Gesonula mundata more difficult to catch compared to Atractomorpha crenulata and Xenocatantops humili.
\end{abstract}

Keywords: Grasshoppers, Jumping distance

\section{Introduction}

Grasshoppers is an insect that belongs to the order of Orthoptera. Grasshoppers are easily found in grass and bush vegetation as in the natural ecosystem. Grasshoppers have the jumping ability to move on one place to another place besides using wings. Other than that, grasshoppers use their jumping ability to escape from predators. According to Hawlena et al. (2011), the jumping speed and jumping distance of grasshoppers will increase with the threat of predators. According to Burrows and Picker (2010), the jumping power will be greater by using both hind legs compared to using one hind leg.

The jumping force and jumping distance of several grasshopper species is not expected to be the same. This is what underlies the idea of this research to find out the jumping distance of several grasshopper species. The benefits of this research can also distinguish the aggressiveness of several species of grasshoppers by looking

at the comparison of jumping distances.

\section{Reseach Methods}

This reseach was conduct in December 2018 in a closed room with a size of $5 \mathrm{~m} \mathrm{x}$ $5 \mathrm{~m}$. The use of a closed room with a size of $5 \mathrm{~m} \times 5 \mathrm{~m}$ by considering the estimated distance of a grasshopper's jumping measured does not exceed $5 \mathrm{~m}$. According to Hawlena et al. (2011), grasshoppers must be acclimatized for 30 minutes to the room that will be used to measure the jumping distance. After being acclimatized the grasshopper's body length will be measured by the distance of the jump. Measurement of grasshopper's jumping distance is done by measuring the initial position of the grasshopper to the grasshopper position after jumping. The jumping distance measured is the jumping distance which is not followed by flapping wings. Also measured is the intensity of light, air temperature and humidity in the room. 


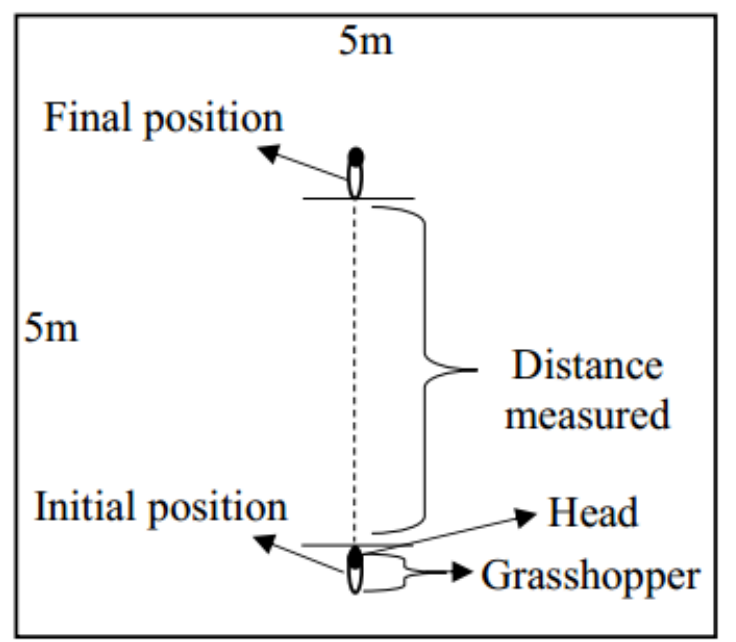

Figure 1. Measurement schema the jumping distance of grasshoppers

Grasshopper species that use measured the jumping distance are Atractomorpha crenulata, Gesonula mundata, Oxya hyla, and Xenocatantops humilis. According to Sugiarto (2018), Atractomorpha crenulata, Gesonula mundata, Oxya hyla, and Xenocatantops humilis are grasshopper species that are easy to find. Other than that, consideration in selection these 4 species of grasshoppers that are estimated to be different jumping distances for each species. Grasshopper species that will be measured the jumping distance was captured using insect net in the rice field ecosystem. Grasshoppers caught are put in jars. Measuring the jumping distance of each grasshopper species was conduct with 5 repetitions, each replication using different individuals. The data obtained is averaged and the standard deviation is sought

\section{Results and Discussion}

Based on the research was conducted, the results obtained are:

Table 1. Average jumping distance on several grasshopper species (Orthoptera)

\begin{tabular}{ll}
\hline Species & Average jumping distance (cm) \\
\hline Atractomorpha crenulata & $55,8 \pm 8,367$ \\
Gesonula mundata & $102,6 \pm 18,721$ \\
Oxya hyla & $107 \pm 12,260$ \\
Xenocatantops humilis & $68 \pm 13,590$ \\
\hline
\end{tabular}

Average jumping distance of Oxya Hyla is longest compared to other grasshoppers species with an average jumping distance of $107 \mathrm{~cm}$, while the jumping distance average of Atractomorpha crenulata is shorter compared to other grasshopper jumping with an average jumping distance of 55.8 $\mathrm{cm}$. Average jumping distance of Gesonula mundata is not far apart to Oxya hyla with an average jumping distance of $102.6 \mathrm{~cm}$. This difference in jumping distance is also thought to cause differences in the presence of grasshoppers in an ecosystem. According to Sugiarto (2018), there are differences in the presence of several grasshopper species in the rice fields ecosystem before and after standing water. When flooded, vegetation in the rice fields area tends to grow in groups, because some vegetation is submerged by standing water. Jump distance ability of Gesonula mundata and Oxya hyla that are farther than Atractomorpha crenulata and Xenocatantops humilis that estimated to cause Gesonula mundata and Oxya hyla tend in be middle of the rice field and Atractomorpha crenulata and Xenocatantops humilis tend to be near the edge of the rice field.

Average length of grasshoppers used in the research was Atractomorpha crenulata $3.32 \mathrm{~cm}$, Gesonula mundata $3.3 \mathrm{~cm}$, Oxya hyla $2.54 \mathrm{~cm}$, and Xenocatantops humilis $2.46 \mathrm{~cm}$. It can be estimated that Gesonula mundata and Oxya hyla are more aggressive in the area of Atractomorpha crenulata and Xenocatantops humilis. This makes Gesonula mundata and Oxya hyla 
more difficult to catch compared to Atractomorpha crenulata and Xenocatantops humilis. According to Queathem and Full (1995), differences of grasshoppers jumping distance are also seen in the instar phase. The jumping distance in this phase is influenced by facto of body mass and production force $r$.

Llight intensity in the room used to measure the grasshopper jumping distance is an average of 143 lux, average air temperature is $29.7 \mathrm{oC}$, and the average air humidity is $89 \%$. According to Almeida and Camara (2008) in addition to physical factors, the type of vegetation in an ecosystem affects the presence of grasshoppers.

\section{Conclusion}

Measuring the jumping distance of several grasshopper species shows a difference in jumping distance. Oxya hyla has the farthest jump distance compared to Atractomorpha crenulata, Gesonula mundata, and Xenocatantops humilis. Crenulata atractomorpha has the shortest jumping distance compared to Oxya hyla, Gesonula mundata, and Xenocatantops humilis. The difference in jumping distance of some species of grasshoppers can illustrate its aggressiveness. Oxya hyla and Gesonula mundata are thought to be more aggressive compared to Atractomorpha crenulata and Xenocatantops humili. It can also estimated that Oxya hyla and Gesonula mundata are more difficult to catch compared to Atractomorpha crenulata and Xenocatantops humili.

\section{References}

Almeida, A.V and Camara, C.A.G. 2008. Distribution of Grasshoppers (Othoptera: Acridoidea) in The Tapacurá Ecological Station (São Lourenço da Mata, PE, Brazil). J. Biol. 68: 21-24.

Burrows, $M$ and M.D. Picker. 2010. Jumping Mechanisms and Performance of Pygmy Mole
Crickets (Orthoptera,

Tridactylidae). Journal of Experimental Biology. 213. 2386-2398.

Hawlena, D., Holger, K., Eric, R.D., and Oswald, J.S. 2011. Grasshoppers Alter Jumping Biomechanics to Enhance Escape Performance Under Chronic Risk of Spider Predation. Functional Ecology. 25. 279-288.

Queathem, E.J and R.J. Full. 1995. Variation in Jump Force Production within an Instar of the Grasshopper Schistocerca americana. J. Zool. 231: 605620.

Sugiarto, A. 2018. An Inventory of Grasshoppers (Orthoptera: Acrididae) in the Plantation and Rice Field Ecosystems of Serdang Menang Village, Sirah Pulau Padang Sub-district, Ogan Komering Ilir District. https://doi.org/10.31227/osf.io/h fxp9. Accessed on Januari 19, 2018.

Sugiarto, A. 2018. Impact of Standing Water on the Existence of Several Species of Grasshoppers (Orthoptera) in the Rice Field Ecosystem. https://doi.org/10.31220/osf.io/a kbgz. Accessed on Januari 19, 2018. 